Revue des sciences de l'eau

Journal of Water Science

\title{
Emploi de la pré-ozonation pour augmenter la biodégradabilité d'un effluent secondaire dans un système de traitement par inflitration dans le sol \\ Preozonation for Enhancing the Biodegradability of Wastewater Effluent in a Potable-Recovery Soil Aquifer Treatment (SAT) System
}

\author{
G. Amy, J. F. Debroux, R Arnold et L. G. Wilson
}

Volume 9, numéro 3, 1996

URI : https://id.erudit.org/iderudit/705258ar

DOI : https://doi.org/10.7202/705258ar

Aller au sommaire du numéro

Éditeur(s)

Université du Québec - INRS-Eau, Terre et Environnement (INRS-ETE)

ISSN

0992-7158 (imprimé)

1718-8598 (numérique)

Découvrir la revue

Citer cet article

Amy, G., Debroux, J. F., Arnold, R. \& Wilson, L. G. (1996). Emploi de la pré-ozonation pour augmenter la biodégradabilité d'un effluent secondaire dans un système de traitement par inflitration dans le sol. Revue des sciences de l'eau / Journal of Water Science, 9(3), 365-380. https://doi.org/10.7202/705258ar
Résumé de l'article

La réutilisation des eaux usées est reconnue comme une technique importante dans les région arides et /ou grandes consommatrices d'eau. L'une des méthodes actuellement très employée consiste à recharger la nappe phréatique avec des effluents secondaires via des bassins d'infiltration. L'épuration biologique et / ou chimique à travers la zone non-saturée représente une caractéristique importante de cette technologie. Les procédés de ce type sont connus sous l'appellation de Soil Aquifer Treatment (SAT) ou géofiltration. Dans ce travail, le procédé a été étudié comme méthode de réhabilitation d'un effluent secondaire d'eaux usées jusqu'au stade d'eau potable. Cette recherche a été principalement axée sur le comportement, le transport des matières organiques (MO) de l'effluent et particulièrement sur leur rôle de précurseurs potentiels de sous-produits de désinfection lors de la réutilisation de la nappe. Dans la zone vadose, la matière organique est principalement éliminée par biodégradation, et à un degré moindre, par adsorption. Les simulations du procédé, en laboratoire, ont été réalisées en réacteurs recirculés aérobies, en mode cuvée, avec un biofilm acclimaté sur des particules de sable siliceux, afin de déterminer la fraction biodégradable des MO. L'évaluation de celle-ci est essentielle pour prédire leur potentiel de dégradation par la biomasse de la zone vadose. L'effluent mis en oeuvre est issu d'une station d'épuration de l'Arizona (États-Unis) avec biofiltre (lit filtrant à support plastique); sa concentration en carbone organique dissous (COD) se situe entre 10 et $15 \mathrm{mg} / \mathrm{L}$.

L'effluent mis 5 jours durant en contact avec le biofilm acclimaté du réacteur montre un abattemen de 50-60 \% du COD. Il a ainsi été déterminé qu'environ $80 \%$ de l'élimination des MO de l'effluent survient dans les premières 24 heures d'expérimentation, alors que le reste, près de $20 \%$, est éliminé durant les 48 heures suivantes. Dans ces conditions, le délai de 5 jours apparait suffisant pour dégrader les MO présentes dans ces effluents. Les rendements observés augurent bien de la dégradation dans la zone vadose si l'on tient compte de la combinaison des taux et de la hauteur d'infiltration avec des temps de résidence de 2 à 14 jours ainsi qu'il est proposé dans le procédé. Afin d'accroître la biodégradabilité des MO, une ozonation a été effectuée, en amont du bio-traitement, avec un générateur d'ozone à l'échelle du banc d'essai fonctionnant en mode semi-continu (admission continue de gaz, volume stable de liquide). La pré-ozonation a permis d'accroître la biodégradation de $60-70 \%$. Bien qu'un fort pourcentage de MO soit éliminé dans ce schéma, il ressort que l'ozone n'a qu'un effet modeste sur la transformation des MO dissoutes

non-biodégradables en matières biodégradables par rapport à des expériences similaires effectuées avec des matières organiques naturelles (MON) des eaux de surface. L'eau usée ainsi traitée présente des niveaux de COD comparables à ceux d'une eau de surface employée à des fins de consommation. Les caractéristiques des MO de l'effluent ont été comparées à celles des MON. Une ultrafiltration de l'effluent pour déterminer le poids moléculaire apparent des MO, donne une distribution bimodale de leur poids moléculaire par rapport à une distribution logarithmique normale observée avec des MON typiques. En utilisant des résines non- ioniques pour séparer les fractions hydrophobes et hydrophiles des MO, il ressort que l'ozonation ne transforme pas de façon significative la fraction hydrophobe des MO de l'effluent en fraction hydrophile, tel que cela a été observé durant l'ozonation des MON. Ces eaux ont été chlorées en pilote, selon des conditions similaires à celles des réseaux de distribution (CI2: $\mathrm{COD}=1: 1 \mathrm{mg} / \mathrm{mg}$, période d'incubation $=24$ heures) afin de simuler la post-désinfection après récupération. Les sous-produits réglementés (Trihalométhanes THM) et ceux proposés (Acides holoacétiques, HAA6) ont été formés à des taux inférieurs ou proches des normes en vigueur (ou de celles proposées pour HAA6) pour l'eau potable aux États-Unis. Cependant, une nitrification significative a été observée dans nos simulations de traitement par le sol avec un effluent non-nitrifié, conduisant à des teneurs en nitrates supérieures à la norme américaine pour l'eau potable $(10 \mathrm{mg} / \mathrm{L})$.
Ce document est protégé par la loi sur le droit d'auteur. L’utilisation des services d’Érudit (y compris la reproduction) est assujettie à sa politique d'utilisation que vous pouvez consulter en ligne.

https://apropos.erudit.org/fr/usagers/politique-dutilisation/ 


\title{
Preozonation for enhancing the biodegradability of wastewater effluent in a potable-recovery soil aquifer treatment (SAT) system*
}

\author{
L'emploi de la pré-ozonisation \\ pour augmenter la biodegradabilité \\ d'un effluent secondaire dans un système \\ de traitement par infiltration dans le sol
}

\author{
G. AMY1**, J.-F. DEBROUX ${ }^{1}$, R. ARNOLD ${ }^{2}$, L.-G. WILSON ${ }^{2}$
}

Reçu le 21 octobre 1994, accepté le 14 mars 1996***.

RÉSUMÉ

La réutilisation des eaux usées est reconnue comme une technique importante dans les régions arides et/ou grandes consommatrices d'eau. $L$ 'une des méthodes actuellement très employée consiste à recharger la nappe phréatique avec des effuents secondaires via des bassins d'infiltration. L'épuration biologique et/ou chimique à travers la zone non-saturée représente une caractéristique importante de cette technologie. Les procédés de ce type sont connus sous l'appellation de * Soll Aquifer Treatment * (SAT) ou géofiltration. Dans ce travail, le procédé a été étudiê comme méthode de réhabilitation d'un effluent secondaire d'eaux usées jusqu'au stade d'eau potable. Cette recherche a été princjpalement axée sur le comportement, le transport des matières organiques (MO) de l'effiuent et particulièrement sur leur rôle de précurseurs potentiels de sous-produits de désinfection lors de la réutilisation de la nappe. Dans la zone vadose, la matière organique est principalement éliminée par biodégradation, et à un degrê moindre, par adsorption. Les simulations du procédé, en laboratoire, ont été réalisées en réacteurs recirculés aérobies, en mode cuvée, avec un biofilm acclimaté sur des particules de sable siliceux, afin de déterminer la fraction biodégradable des MO. L'évaluation de celle-ci est essentielle pour prédire leur potentiel de dégradation par la biomasse de la zone vadose. L'effiuent mis en oeuvre est issu d'une station d'épuration de l'Arizona (ÉtatsUnis) avec biofiltre (lit filtrant à support plastique) ; sa concentration en carbone organique dissous (COD) se situe entre 10 et $15 \mathrm{mg} / \mathrm{L}$.

1. University of Colorado at Boulder.

2. University of Arizona.

* Communication présentée au Colloque international sur la "Matière organique biodégradable ", Ecole Polytechnique de Montréal, juin 1994.

* Please address all inquiries to above author at: University of Colorado, Campus Box 428, Boulder, CO, USA 80309.

***Les commentaires seront reçus jusqu'au 15 juin 1997. 
L'effluent mis, 5 jours durant, en contact avec le biofilm acclimaté du réacteur, montre un abattement de 50-60\% du COD. Il a ainsi été déterminé qu'environ $80 \%$ de l'élimination des MO de l'effluent survient dans les premières 24 heures d'expérimentation, alors que le reste, près de $20 \%$, est éliminé durant les 48 heures suivantes. Dans ces conditions, le délai de 5 jours apparait suffisant pour dégrader les MO présentes dans ces effluents. Les rendements observés augurent bien de la dégradation dans la zone vadose si l'on tient compte de la combinaison des taux et de la hauteur d'infiltration avec des temps de résidence de 2 à 14 jours ainsi qu'il est proposé dans le procédé. Afin d' accrôtre la biodégradabilité des MO, une ozonation a été effectuée, en amont du bio-traitement, avec un générateur d'ozone à l'échelle du banc d'essai fonctionnant en mode semi-continu (admission continue de gaz, volume stable de liquide). La pré-ozonation̂ a pérmis d'accrô̂tre la biodégradation de 60-70 \%. Bien qu'un fort pourcentage de MO soit éliminé dans ce schéma, il ressort que l'ozone n'a qu'un effet modeste sur la transformation des MO dissoutes non-biodégradables en matières biodégradables par rapport à des expériences similaires effectuées avec des matières organiques naturelles (MON) des eaux de surface. L'eau usée ainsi traitée présente des niveaux de COD comparables à ceux d'une eau de surface employée à des fins de consommation. Les caractéristiques des MO de l'effluent ont été comparées à celles des MON. Une ultrafiltration de l'effluent pour déterminer le poids moléculaire apparent des MO, donne une distribution bimodale de leur poids moléculaire par rapport à une distribution logarithmique normale observée avec des MON typiques. En utilisant des résines non-ioniques pour séparer les fractions hydrophobes et hydrophiles des MO, il ressort que I'ozonation ne transforme pas de façon significative la fraction hydrophobe des MO de l'efiluent en fraction hydrophile, tel que cela a été observé durant l'ozonation des MON. Ces eaux ont été chlorées en pilote, selon des conditions similaires à celles des réseaux de distribution $\left(\mathrm{Cl}_{2}\right.$ : COD $=1: 1 \mathrm{mg} / \mathrm{mg}$, période d'incubation $=24$ heures) afin de simuler la postdésinfection après récupération. Les sous-produits réglementés (Trihalométhanes THM) et ceux proposés (Acides holoacétiques, HAA6) ont été formés à des taux inférieurs ou proches des normes en vigueur (ou de celles proposées pour HAA6) pour l'eau potable aux États-Unis. Cependant, une nitrification significative a été observée dans nos simulations de traitement par le sol avec un effluent non-nitrifié, conduisant à des teneurs en nitrates supérieures à la norme américaine pour l'eau potable $(10 \mathrm{mg} / \mathrm{L})$.

Mots clés : matières organiques, biodégradabilité, eau usée, ozone, géofiltration.

\section{SUMMARY}

Soil Aquifer Treatment (SAT) is being studied as a means of water quality renovation of a secondary effluent for potable reuse. During SAT, infiltration of effluent through the vadose zone provides removal of effluent organic matter primarily through biodegradation, and to a lesser extent, through sorption. A major concern is that effuent organic matter can function as disinfection byproduct (DBP) precursors upon recovery and post-disinfection. Through laboratory simulations of SAT, we have found that $50-60 \%$ of the dissolved organic carbon (DOC) present in secondary effluent can potentially be removed by biodegradation, with preozonation increasing removal to $60-70 \%$. The resultant water contains DOC at levels comparable to a typical surface water used for potable purposes; moreover, upon chlorination, regulated DBPs are formed at levels below or near the United States of America's drinking water standards. However, significant nitrification was observed in our SAT simulations with an un-nitrified effluent, yielding levels of nitrate above the USA drinking water standard.

Key words : organic matter, biodegradability, ozone, wastewater, soil treatment. 


\section{INTRODUCTION}

Due to increasing water use generated by increasing demand, wastewater reuse is recognized as an important water conservation technique in arid and/or high water use regions throughout the world (BOUWER et al., 1980; BOUWER and RICE, 1984). This research proposes the use of SAT, utilizing secondary effluent, as a potential alternative to tertiary wastewater treatment. A SAT system involves effluent infiltration through a recharge basin, contaminant removal by biodegradation and/or sorption within the vadose zone, and subsequent recovery of SATtreated water from the saturated zene through pumping wells. Improvement of water quality at numerous SAT sites has been observed (BOUWER et al., 1974, 1980; BOUWER and RICE, 1984; ASANO et al., 1985; JOHNSON and FINLAYSON, 1989). Due to the uncertainty of the fate and transport of wastewater organics (JOHNSON and FINLAYSON, 1989; AMY et al., 1993) (which can act as DBP precursors in potable reuse), pathogenic microorganisms (ASANO et al., 1985), and nitrate $\left(\mathrm{NO}_{3}{ }^{-}\right)$, it has been recommended that wastewater recovered after SAT be used for nonpotable applications (JOHNSON and FINLAYSON, 1989).

Past work by the current investigators involving pilot-scale lysimeters showed DOC and total organic halide (TOX) removals of $50 \%$ and $30 \%$, respectively, over a six meter depth, with the most removal occurring within the first meter (AMY et al., 1993). Related field studies involving a vadose zone depth profile of 30 meters showed even greater removals. However, even with this reduction, the remaining $D O C$, on the order of several $\mathrm{mg} / \mathrm{L}$, can still function as $D B P$ precursors during disinfection of recovered water. Operational concerns (i.e., maintaining infiltration rates) require the use of (coarse) soil types less amenable to sorption; hence, the burden for organic matter removal in SAT falls upon biodegradation. Moreover, biodegradation assumes added importance from the perspective of process sustainability. While wastewater effluent treated by conventional biological treatment is generally considered to be biologically stabilized, further DOC removal is possible by soil bacteria over longer time frames. Nevertheless, a fraction of the effluent DOC is biorefractory.

The application of ozone to potable source waters increases the biodegradability of natural organic matter (NOM) (SERVAIS et al., 1991; MURPHY, 1993). The oxidation of NOM, which consists of a variety of large complex organic molecules, by ozonation results in smaller, more readily degradable organic compounds (SERVAIS et al., 1991; VOLK et al., 1993; MILTNER et al., 1992). Due to deteriorating source water quality in European surface waters, ozonation in combination with biofiltration has been utilized to remove DBP precursors in western Europe since the 1970's (KNOPPERT et al., 1980).

Due to the realization of the effects of excessive chlorine use, ozone has been utilized during wastewater treatment in the United States since the 1970's, although primarily as a disinfectant (ROBSON and RICE, 1991). Ozonation, used as pretreatment prior to SAT, has the potential to increase the biodegradability and, hence, increase the removal of organic matter within wastewater effluent. If wastewater is to be considered as a possible potable water source, specific organic halides that are presently regulated, or may be in the future, by drinking water standards are of concern. Currently in the United States, these compounds are trihalomethanes (THM) and haloacetic acids (HAA). These compounds are formed when secondary effluent is disinfected with chlorine and again if chlorine is 
utilized within the potable water treatment process train. In this study, organic haljdes formed during disinfection of secondary effluent will be referred to as background DBPs while the DBPs formed during simulated potable water disinfection will be referred to as the DBP formation under simulated distribution system conditions (SDS-DBPs).

The primary objective of this research is to delineate the role of pretreatment in transforming biorefractory effluent organics into biodegradable by-products more amenable to removal by SAT.

\section{METHODS AND PROCEDURES}

Table 1 lists the water quality parameters for the secondary effluent utilized. This effluent was derived from a biotower (plastic media trickling filter), with typical DOC levels of approximately $10-15 \mathrm{mg} / \mathrm{L}$. Two different samples of the effluent were collected from the same wastewater treatment in the winter and spring of 1994. All pertinent characteristics of Silver Lake source water may be found in MURPHY (1993) as data collected during previous research conducted by Murphy and the primary author are utilized here to compare surface water NOM and effluent organic matter (EFOM), with respect to their biodegradability and to the effects of ozonation on their biodegradability. Effluent samples were ozonated based on transferred $\mathrm{O}_{3} / \mathrm{DOC}$ ratios of $0.8,1.6$ and $2.4 \mathrm{mg} / \mathrm{mg}$ delivered using a semi-batch, lab scale ozonation system manufactured by Ozone Science \& Equipment Corp. (OREC O3V5-0, Phoenix, AZ, USA). These three ozonated waters were studied along with a non-ozonated control water. Biodegradable dissolved organic carbon (BDOC) was measured in both the non-ozonated and ozonated samples. BDOC represents the difference in DOC over a five day period of sample recirculation through sand with an acclimated biofilm, and corresponds to the biodegradable fraction of the bulk DOC. The five day length of the BDOC test provides a measure of the ultimate biodegradation possible during soil infiltration as the BDOC reactor simulates the soil mantle. In our protocol, there are three sampling points: non-ozonated, post-ozonated, and post-biotreated (i.e., the final contents of the BDOC reactor) waters. (Hereafter, the BDOC-reactor treated water corresponds to the terminology biotreated). Each of the samples was also characterized according to DOC and chlorination SDS-DBPS.

Upon receipt of the wastewater, residual $\mathrm{Cl}_{2}$ was measured then dechlorinated with a stoichiometric concentration of sodium thiosulfate. Prior to insertion into the BDOC reactors, the wastewater was filtered through a $1 \mu \mathrm{m}$ glass fiber filter (Gelman Sciences Corp., Ann Arbor, MI, USA) to remove suspended solids, and all DOC measurements were performed after filtration through a pre-rinsed 0.45 $\mu \mathrm{m}$ filter (Millipore Corp., Bedford, MA, USA).

Two different sources of bacteria were utilized for BDOC experiments. The first were bacteria from a local surface water collected with an in-line sand filter at the intake of the local water utility for a period of thirty days. The second set of bacteria were acclimated onto a sand bed with the source being a combination of a) chlorinated, then dechlorinated, secondary effluent, b) non-chlorinated secondary effluent, and c) soil bacteria taken from a soil sample extracted from a SAT site. 
Table 1 Aaw Effluent Water Quality Characteristics.

Tableau 1 Caractéristiques de l'effluent brut.

\begin{tabular}{|c|c|c|c|c|c|}
\hline Effluent ${ }^{a}$ & $\begin{array}{c}\text { TOC } \\
(\mathrm{mg} / \mathrm{L})\end{array}$ & $\begin{array}{c}D O C \\
(m g / L)\end{array}$ & $\begin{array}{l}\mathrm{UVA}_{254} \\
\left(\mathrm{~cm}^{2}\right)^{2}\end{array}$ & $\mathrm{UVA}_{254} / \mathrm{DOC}$ & pH \\
\hline$\# 1$ & 15.4 & 12.9 & 0.179 & 0.0139 & 7.3 \\
\hline$\# 2$ & 16.1 & 14.2 & 0.190 & 0.0134 & 7.2 \\
\hline
\end{tabular}

\begin{tabular}{|c|c|c|c|c|}
\hline Effluenta & $\begin{array}{c}\text { Alkalinity } \\
\left.\text { (mg/L as } \mathrm{CaCO}_{3}\right)\end{array}$ & $\begin{array}{r}\mathrm{NH}_{3}-\mathrm{N} \\
-(\mathrm{mg} / \mathrm{L})\end{array}$ & $\begin{array}{c}\mathrm{NO}_{3}{ }^{-}-\mathrm{N}^{\mathrm{b}} \\
(\mathrm{mg} / \mathrm{L})\end{array}$ & $\begin{array}{l}\mathrm{PO}_{4}{ }^{3-\mathrm{b}} \\
(\mathrm{mg} / \mathrm{L})\end{array}$ \\
\hline$\# 1$ & 212 & 16.2 & 0.23 & 11.8 \\
\hline$\# 2$ & 205 & 27.9 & 0.36 & 10.2 \\
\hline
\end{tabular}

- Effuents 1 and 2 sampled in the winter and spring of 1994, respectively.

- Concentrations determined by ion chromatography (DX-300 IC, Ion Pac AS9, Dionex Corp., Sunnyvale, CA, USA).

The sands containing the biofilms were gently, but thoroughly, washed prior to placement into the reactors. To assure consistency, the data presented for this study represent the wastewater-based BDOC which was solely degraded by the second set of bacteria.

Bench scale ozonation was conducted using an Orec $110 \mathrm{gram} /$ day ozone generator and a 2.75 liter capacity impeller reactor/contactor. Ozone was generated from high purity oxygen ( $\sim 5 \%$ ozone) and admitted to the reactor in a semibatch mode (continuous gas admission, static liquid volume). Applied ozone dose ( $\mathrm{mg} / \mathrm{L}$ ) was controlled by the mass flow rate into the reactor $(\mathrm{mg} / \mathrm{L}-\mathrm{min})$ and contact time $(\mathrm{min})$. While experiments were based on transferred ozone dose, both applied and utifized ozone were determined for each experiment in order to insure the anticipated transfer efficiency $(\sim 30 \%)$. Ozone by-products, including aldehydes (formaldehyde, acetaidehyde, glyoxal, and methyl glyoxal) and ketoacids (glyoxylic acid, pyruvic acid, and ketomalonic acid), were monitored as chemical surrogates for biodegradability.

The BDOC reactors utilized consist of a system of vacuum recirculating glass batch reactors, designed originally by MOGREN et al. (1990). Each reactor consists of a glass container which contains acclimated biofilm on sand, and the sample. The wastewater flows through the sand/biofilm gravitationally and is then reintroduced by suction through a return line. Recirculating flow rates for each reactor are adjustable and flow rates were maintained at approximately 30 $40 \mathrm{ml} / \mathrm{min}$ allowing complete sample contact with the biofilm every ten minutes. Air is also introduced at the return line to assure aerobic conditions. To minimize the introduction of organic carbon into the system from the feed air, a system of filters is utilized in series. This system consists of a GAC column, a $0.3 \mu \mathrm{m}$ hepa filter, and a series of two air scrubbing bottles filled with high purity "Milli- $Q$ " water (Millipore Corp., Bedford, MA, USA). The BDOC data presented for this study represent the mean of $\mathrm{BDOC}$ experiments in five reactors which were performed simultaneously. The greatest variation in DOC concentrations in all BDOC experiments was $\pm 8.1 \%$. Table 2 lists the coefficients of variance (CVs) for the experimental and analytical analyses performed for this study. Analytical CVs were based upon reproducibility of data when $10 \%$ of the samples were analyzed in triplicate. These percentages represent the sensitivity of a particular analytical ins- 
trument towards a particular water quality parameter, whereas the experimental CVs incorporate the error associated with performing the experiment prior to analysis (i.e., bench scale chlorination, incubation, and extraction within a SDS-THMs experiment).

The bulk DOC present at the various sampling points is characterized according to low versus high molecular weight (MW) DOC fractions, and humic (hydrophobic) versus non-humic (hydrophilic) DOC fractions. Molecular weight/size separation was performed using Amicon ultrafiltration $Y M-1$ and $Y M-10$ (apparent molecular weight cutoff equal to 1,000 and 10,000 daltons, respectively) membranes in an Amicon stirred cell (Amicon Corp., Danvers, MA, USA). The humic and non-humic fractions "of the effluent DOC were separated by adsorption of the humics onto Amberlite 20-40 mesh XAD-8 nonionic resin (Rohm \& Haas Company, Philadelphia, PA , USA) in the manner described by LEENHEER (1981).

Table 2 Analytical and Experimental Replication Analysis.

Tableau 2 Reproductibilité analytique et expérimentale.

\begin{tabular}{|c|c|c|c|c|}
\hline \multirow{2}{*}{ Parameter } & \multirow{2}{*}{ Units } & \multicolumn{2}{|c|}{ C.V. $(\%)^{a}$} & \multirow{2}{*}{ MDL' } \\
\hline & & Analytical & Experimental & \\
\hline TOC $(<1 \mu \mathrm{m})^{\mathrm{C}}$ & $\mathrm{mg} / \mathrm{L}$ & $<2$ & $n / a^{d}$ & 0.2 \\
\hline$D O C^{C}$ & $\mathrm{mg} / \mathrm{h}$ & $<2$ & $n / a$ & 0.2 \\
\hline $\mathrm{BDOC}$ & $\mathrm{mg} / \mathrm{L}$ & $<2$ & 8.1 & 0.2 \\
\hline $\mathrm{UVA}_{254^{\mathrm{e}}}$ & $\mathrm{cm}^{-1}$ & 3.41 & $n / a$ & 0.001 \\
\hline $\mathrm{pH}^{f}$ & $n / a$ & 0.9 & $n / a$ & $n / a$ \\
\hline Alkalinityg & $\begin{array}{c}\mathrm{mg} / \mathrm{L} \text { as } \\
\mathrm{CaCO}_{3}\end{array}$ & 2.99 & $n / a$ & 10 \\
\hline Total $\mathrm{NH}_{3}-\mathrm{N}^{\mathrm{h}}$ & $\mathrm{mg} / \mathrm{L}$ & 8.45 & $n / a$ & 0.01 \\
\hline $\mathrm{THMS}^{\mathrm{i}}$ & $\mu g / L$ & 0.78 & 5.3 & 0.5 \\
\hline $\mathrm{HAA}_{6} \mathrm{~S}^{\mathrm{i}}$ & $\mu g / L$ & 2.55 & 4.2 & 1.0 \\
\hline $\mathrm{Cl}_{2}$ Residual $^{\mathrm{h}}$ & $\mathrm{mg} / \mathrm{L}$ & 4.0 & $n / a$ & 0.05 \\
\hline
\end{tabular}

- Coefficient of variance.

- Minimum detection limit.

c Shimadzu TOC-5000 carbon analyzer, Columbia, MD, USA.

- Not applicable.

- Shimadzu UV-160A UV-Visible spectrophotometer,

Columbia, MO, USA.

1 Orion Inc., Cambridge, MA, USA.

- Standard Methods, APHA, 1989.

'Hach Chemical Co., Loveland, CO, USA.

1 Gas chromatography, Hewlett Packard 5890, Avondale, PA, USA.

Aliquots of each sample were also subjected to a DBP formation potential (THMsSDS, HAA 6 SDS) tests to identify the formation of THM and HAA upon chlorination. All four THM species and six HAA species were measured, but the results reported are total THM and HAA-six (THMs and HAA, respectively). The formation potential tests were based upon simulated distribution system test criteria which are a $\mathrm{Cl}_{2} / \mathrm{DOC}$ ratio of $1 \mathrm{mg} / \mathrm{mg}$ beyond the ammonia breakpoint dose, a temperature of $20^{\circ} \mathrm{C}$, an ambient $\mathrm{pH}$, and a reaction time of 24 hours; the protocol also included a quantitative test for chlorine residual. Measurements of $\mathrm{NH}_{3}-\mathrm{N}$ were made to adjust the indicated applied chlorine doses to account for this inorganic demand. 


\section{RESULTS AND DISCUSSION}

We adapted the recirculating sand reactor approach for $\mathrm{BDOC}$ determinations to waste water effluent, but found that an acclimation period is necessary for BDOC reactors containing sand acclimated with surface-water bacteria. Parallel experiments were performed with BDOC reactors containing sand and either (i) surface-water bacteria acclimated to NOM or (ii) waste water effluent bacteria acclimated to effluent organics. Using surface-water bacteria for successive fiveday tests (i.e., reactor contents drained/analyzed every five days and replaced by new feed water), we found that sequential BDOC measurements made after each five-day cycle increased from about $25 \%$ to about $50 \%$ of the DOC (Fig. 1). Conversely, in reactors containing effluent acclimated bacteria, BDOCs reflecting $50-60 \%$ of the DOC were measured over the first cycle, and thereafter. Previous work by MOGREN et al. (1990) showed that sand can be acclimated with any surface water, and subsequently used for BDOC determinations for other surface waters; however, it is apparent that further acclimation is needed to degrade effluent organic matter. The BDOC of the non-ozonated secondary effluent was determined to be approximately $50-60 \%$ of the DOC, indicating that a significant fraction of the DOC remaining after biological secondary treatment can be biodegraded if long enough residence times are provided.

The kinetics of BDOC exertion (Fig. 2) indicate that a large majority of the biodegradable organic matter present in effluent is utilized within the first day of a five-day cycle. The kinetics of BDOC exertion exhibit two general components: a rapidly degradable component $\left(B D O C_{\text {rapid }}\right)$ removed within the first 24 hours or

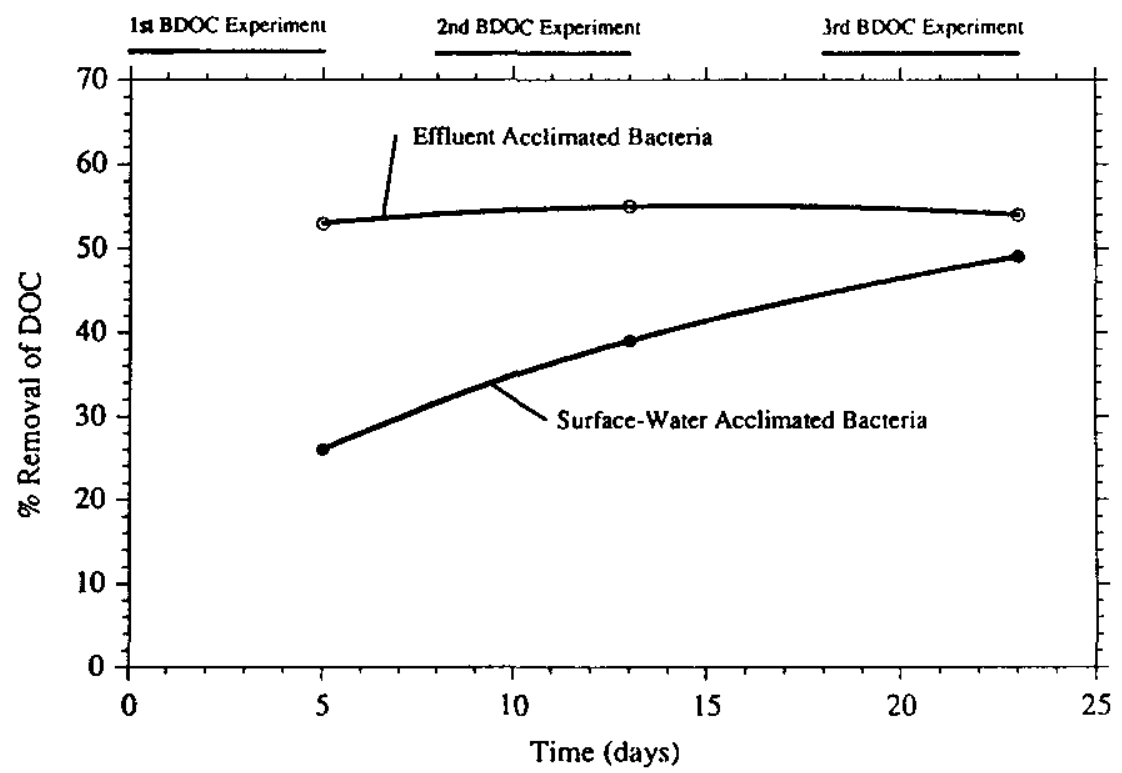

Figure 1 Successive $B D O C$ cycles using surface-water-acclimated bacteria or effluent-acclimated bacteria.

Déterminations successives du CODB avec des substrats colonisés par des bactéries provenant soit de l'eau de surface, soit de l'effluent. 


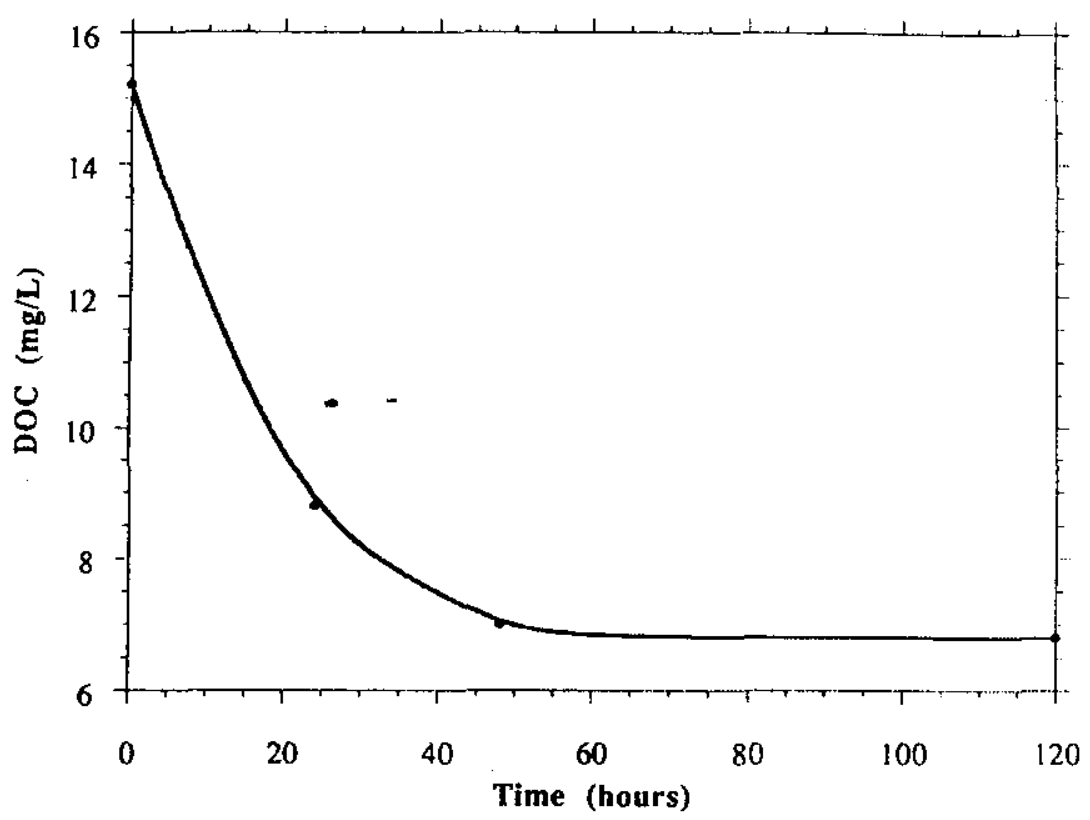

Figure 2 Typical kinetics of BDOC removal.

Cinétique typique pour la disparition du CODB.

less (corresponding to about $80 \%$ of the overall BDOC), and a slowly degradable component $\left(\mathrm{BDOC}_{\text {stow }}\right.$ ) removed thereafter. In our previous pilot (lysimeter) studies, the travel time during infiltration through a six meter depth of the vadose zone at a field site was estimated to be about six hours; transport times through the entire approximately 30 meter vadose zone associated with this field site are estimated to be greater than 24 hours. Thus, SAT affords an opportunity to achieve near complete removal of $\mathrm{BDOC}_{\text {rapid }}$ and some of $\mathrm{BDOC}_{\text {slow }}$

The effects of ozonation on BDOC formation are shown in Figure 3, contrasting effluent with a typical surface water. It can be seen that preozonation has much less effect on the biodegradability of effluent organic matter, compared to surface water NOM. Typically, in a surface water, the BDOC represents approximately $10 \%$ of the DOC without ozonation; preozonation can increase this to as high $50 \%$ (MURPHY, 1993). In contrast, effluent organic matter exhibits a "higher intercept" and a "lesser slope" response. The BDOC of the non-ozonated effluent, corresponding to about $50-60 \%$ of the DOC, was increased to about $60-70 \%$ of the DOC upon ozonation.

We also defined the character of effluent organic matter according to standard NOM fractionation protocols, including MW, and humic/hydrophobic versus nonhumic/hydrophilic character. The ultrafiltration protocols separate DOC into lower (permeate) and higher (retentate) MW fractions. The XAD-8 isolate is operationally defined as the humic or hydrophobic fraction of the DOC; the remaining DOC is defined as non-humic or hydrophilic DOC. Based on work with surface waters (AMY, 1992), BDOC has been shown to correlate with either lower MW DOC or non-humic DOC. 


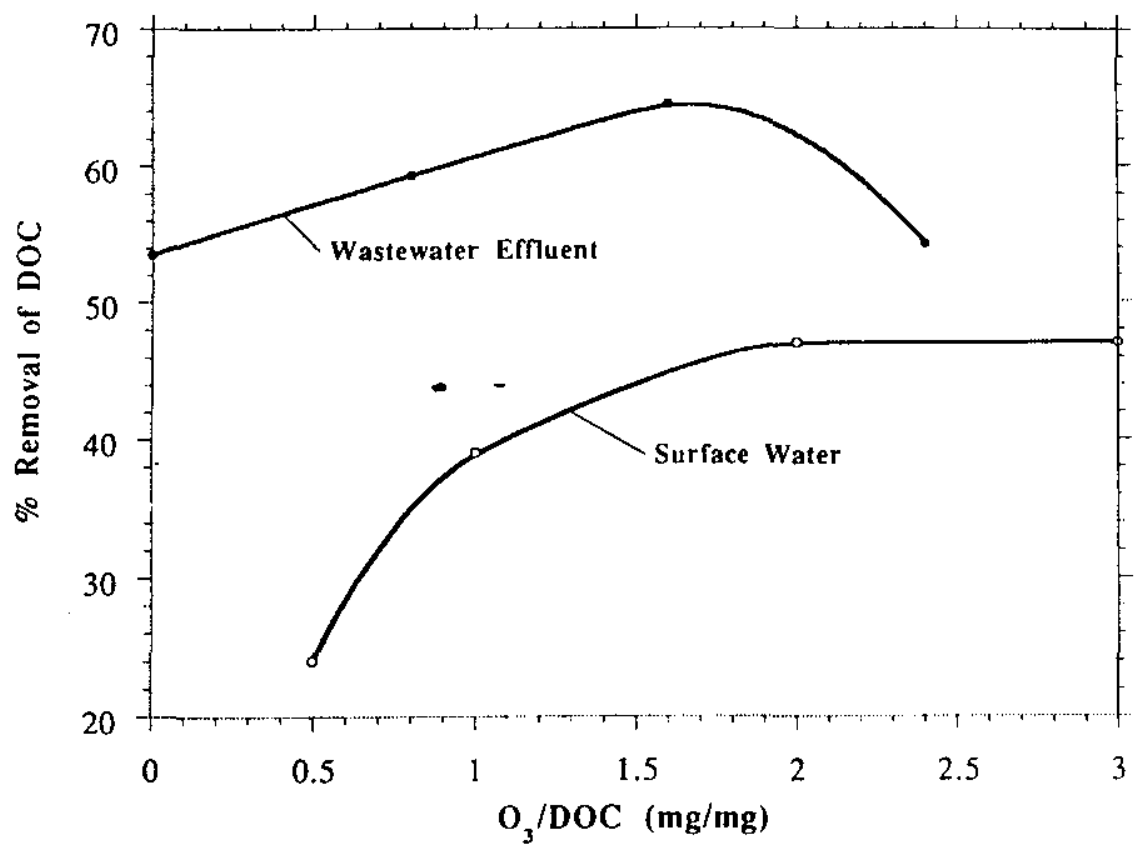

Figure 3 Conversion of DOC to BDOC by ozononation of surface water (Silver Lake) and secondary effluent sources.

Transformation du COD en CODB lors de l'ozonisation d'une eau de surface (Silver Lake) et d'un effluent secondaire.

Consistent with previous work by SAUNDERS (1981), we observed a bi-modal MW distribution of effluent DOC, with significant fractions less than 1,000 and greater than 10,000 daltons (Fig. 4). This is in contrast to surface waters which generally contain little material above 5,000 daltons (THURMAN, 1985). Ozonation transformed some higher MW (> 10,000 daltons) to lower MW (1,000-10,000 daltons) material; biotreatment showed degradation of material from all $\mathrm{MW}$ fractions, suggesting that higher MW constituents of effluent organic matter are more biodegradable than those associated with surface water NOM. The humic and non-humic content of effluent DOC (Fig. 5) was generally similar to that of surface waters (THURMAN, 1985). Unlike surface water NOM, ozonation had little effect in transforming hydrophobic (humic) to hydrophilic (non-humic) DOC, suggesting that effluent organic matter is less reactive with ozone. Both humic and nonhumic constituents were removed in the BDOC test, suggesting that the XAD-8 isolate from effluent may not be similar to surface water humic substances.

Secondary effluent samples were also characterized according to chemical surrogates for biodegradability (aldehydes and ketoacids). Total aldehyde plus ketoacid concentrations of about $15 \mu \mathrm{g} / \mathrm{L}$ were observed in non-ozonated effluent, in contrast to surface waters where aldehyde and ketoacid concentrations are near detection limits. Ozonation increased these levels significantly, particularly for formaldehyde, with subsequent removal by biotreatment to leveis found before ozonation (Fig. 6). 


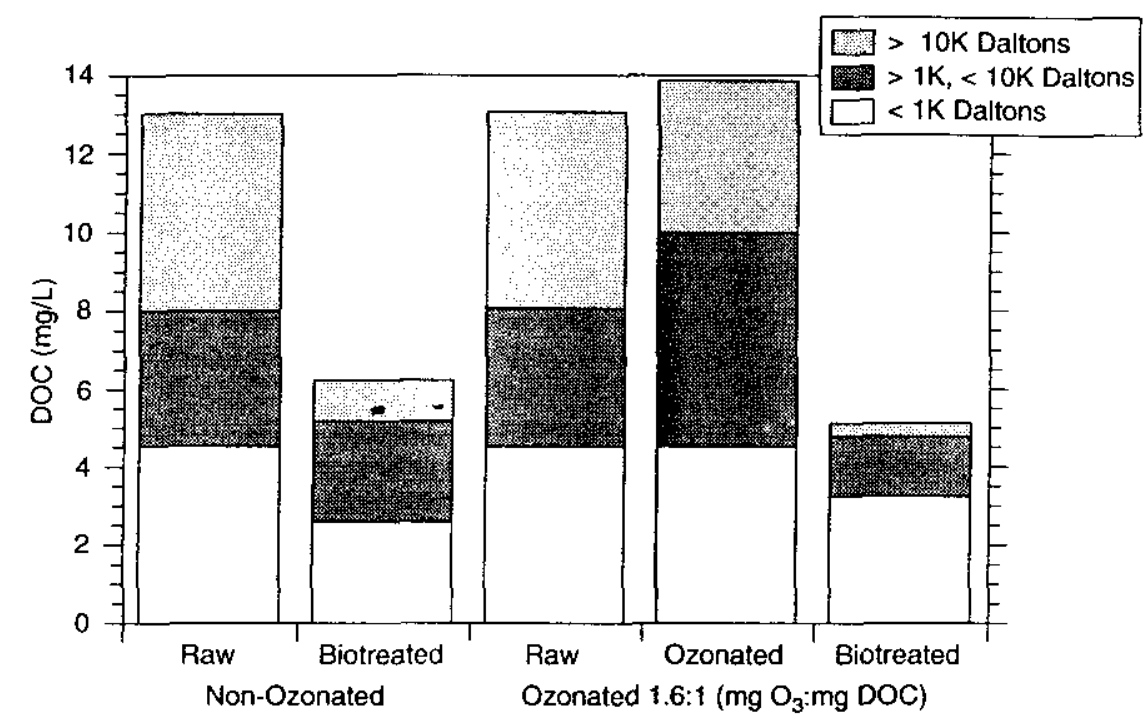

Figure 4 Fractionation of DOC $(<0.45 \mu \mathrm{m})$ by subsequent ultrafiltration: effect of biotreatment and ozonation.

Séparation du COD $(<0,45 \mu \mathrm{m})$ par ultrafiltration subséquente : effet du biotraitement et de l'ozonisation.

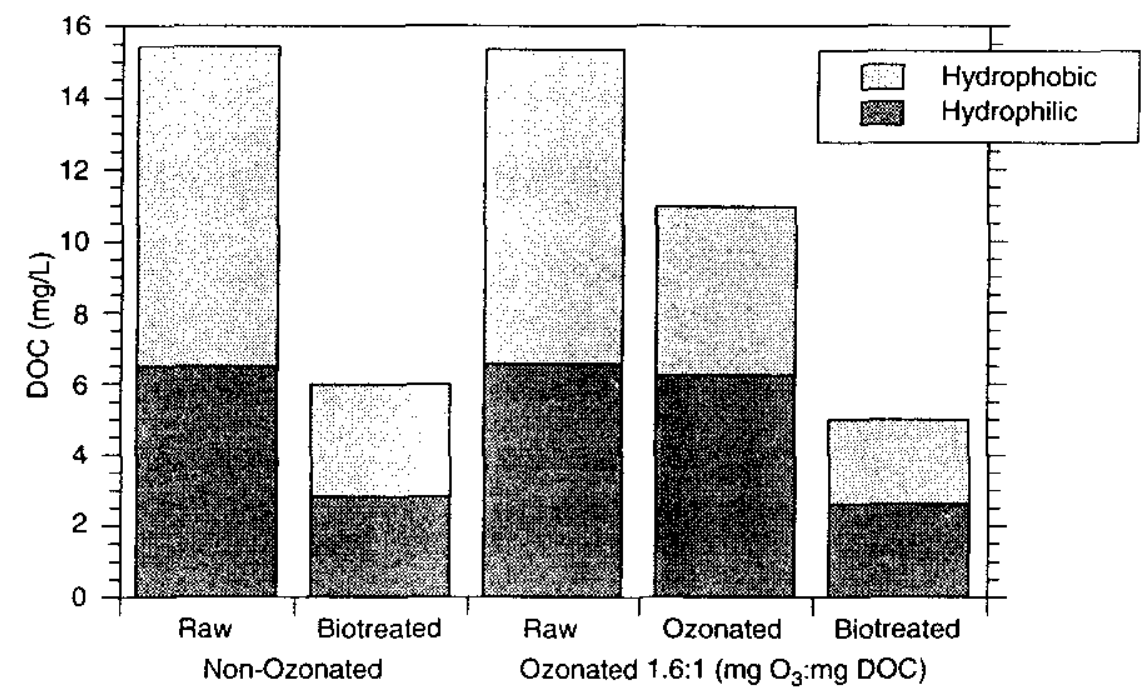

Figure 5 Fractionation of DOC $(<1 \mu \mathrm{m})$ on $X A D-8$ resin: effect of biotreatment and ozonation.

Séparation du COD $(<1 \mu \mathrm{m})$ sur résine XAD-8 : effet du biotraitement et de f'ozonisation. 
SDS-THMs and SDS-HAA 6 were measured on the effluent before and after biotreatment (Fig. 7 and 8). Upon chlorination, the untreated effluent exhibited THMs above the current USA drinking water standard of $100 \mu \mathrm{g} / \mathrm{L}$ (proposed drinking water standards are $80 \mu \mathrm{g} / \mathrm{L}$ THMs and $60 \mu \mathrm{g} / \mathrm{L} \mathrm{HAA}$ for Stage 1, $40 \mu \mathrm{g} / \mathrm{L}$ THMs and $30 \mu \mathrm{g} / \mathrm{L}$. HAA6 for Stage II; all analyses reported include the sixth HAA, bromochloracetic acid, which never accounted for more than $9 \%$ of HAA6). Upon biotreatment alone, the THMs level was reduced to well below the standard while the $\mathrm{HAA}_{6}$ level was near the standard. With ozone-biotreatment, both THMs and $\mathrm{HAA}_{6}$ were further reduced. It is apparent that biotreatment is more effective in removing THMs then $\mathrm{HAA}_{6}$ precursors, and that $\mathrm{HAA}_{6}$ may form in biotreated effluents at levels near the proposed drinking water standard. As received, the secondary effluent had been chlorinated with $6 \mathrm{mg} / \mathrm{L}$; background levels of TOX (total organic halide), $\mathrm{HAA}_{6}$ and THMs were approximately $100 \mu \mathrm{g} / \mathrm{L}$, about $15 \mu \mathrm{g} / \mathrm{L}$, and near the detection limit, respectively. Upon receipt of the wastewater effluent, the chlorine residuals were measured as 1.2 and $1.3 \mathrm{mg} / \mathrm{L}$ for Effluents 1 and 2, respectively, which were dechlorinated prior to experimentation or analysis.

It is noteworthy that SDS-DBP tests involved chlorination at a dose of $\mathrm{Cl}_{2} / \mathrm{DOC}$ $=1 \mathrm{mg} / \mathrm{mg}$ plus the breakpoint dose. For the effluent without biotreatment, the substantial ammonia concentration (Table 1) required high concentrations of chlorine as part of the breakpoint reaction (Fig. 9); conversely, after biotreatment and nitrification (see discussion below), much lower chlorine doses were applied to the effluent (Fig. 10). It is apparent that chloramines are much more effective in reducing THMs than $\mathrm{HAA}_{\delta}$ formation during chlorination of effluent organic matter in the presence of ammonia (Table 2).

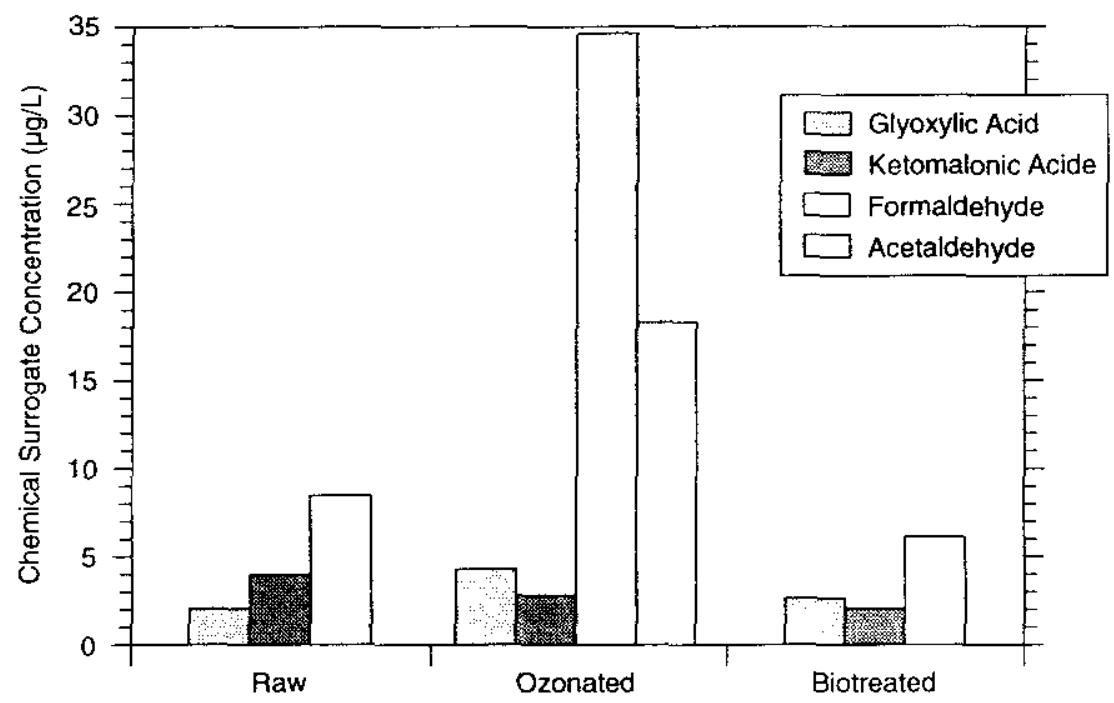

Ozonated 1.6:1 (mg $\left.\mathrm{O}_{3}: \mathrm{mg} \mathrm{DOC}\right)$

Figure 6 Concentrations of chemical surrogates in raw, ozonated and treated effluent.

Concentrations d'aldéhydes et d'acides cétoniques dans un effluent secondaire: effet du biotraitement et de l'ozonisation. 


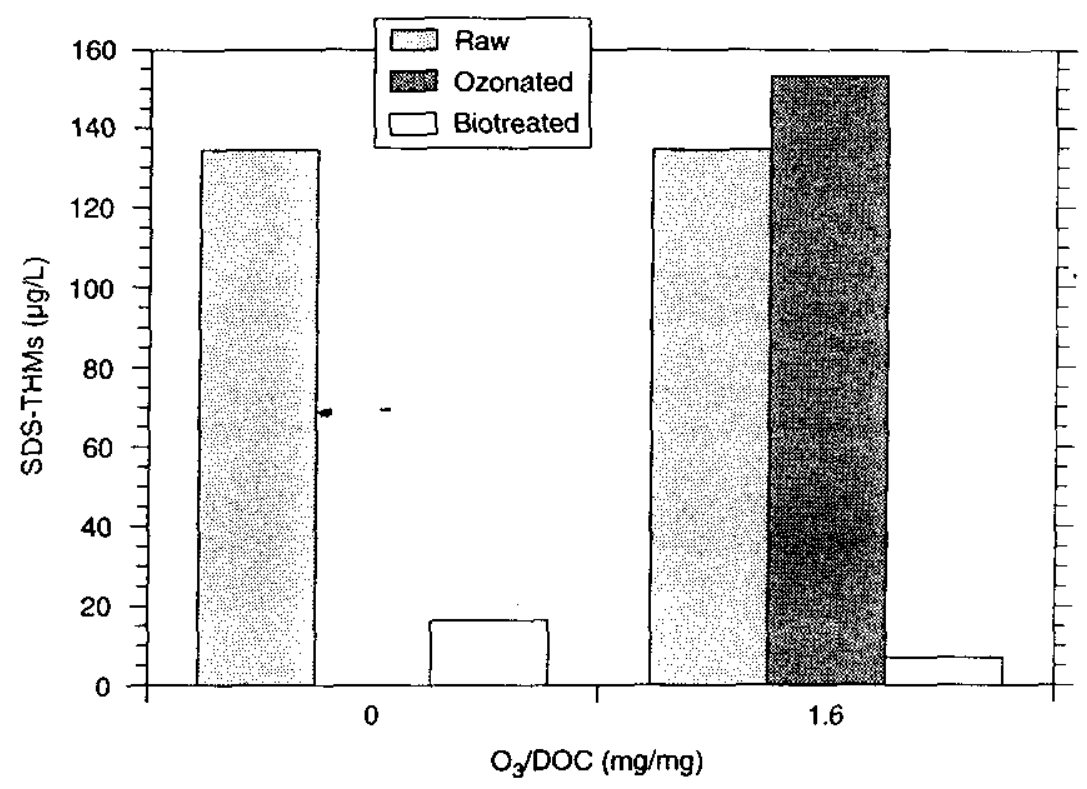

Figure 7 Formation of trihalomethanes under simulated distribution system conditions. Formation de trihalométhanes dans des conditions simulant des réseaux de distribution d'eau potable.

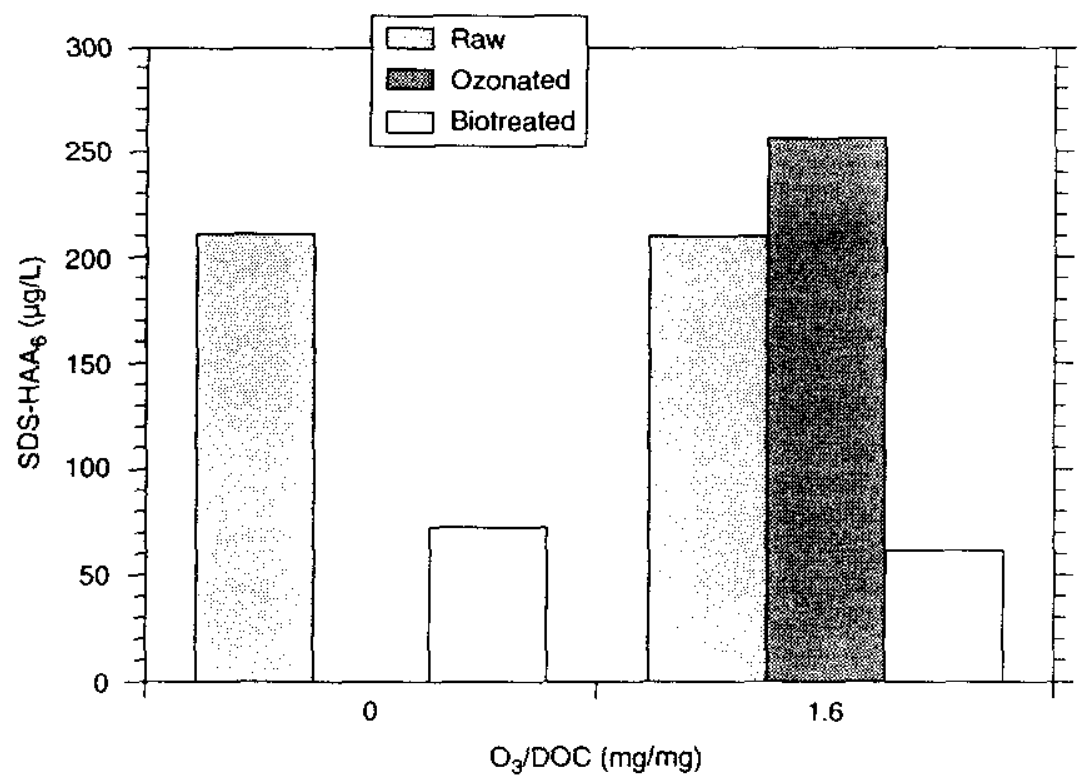

Figure 8 Formation of haloacetic acids $\left(H A A_{6}\right)$ under simulated distribution system conditions.

Formation d'acides haloacétiques $\left(\mathrm{HAA}_{6}\right)$ dans des conditions simulant des réseaux de distribution d'eau potable. 


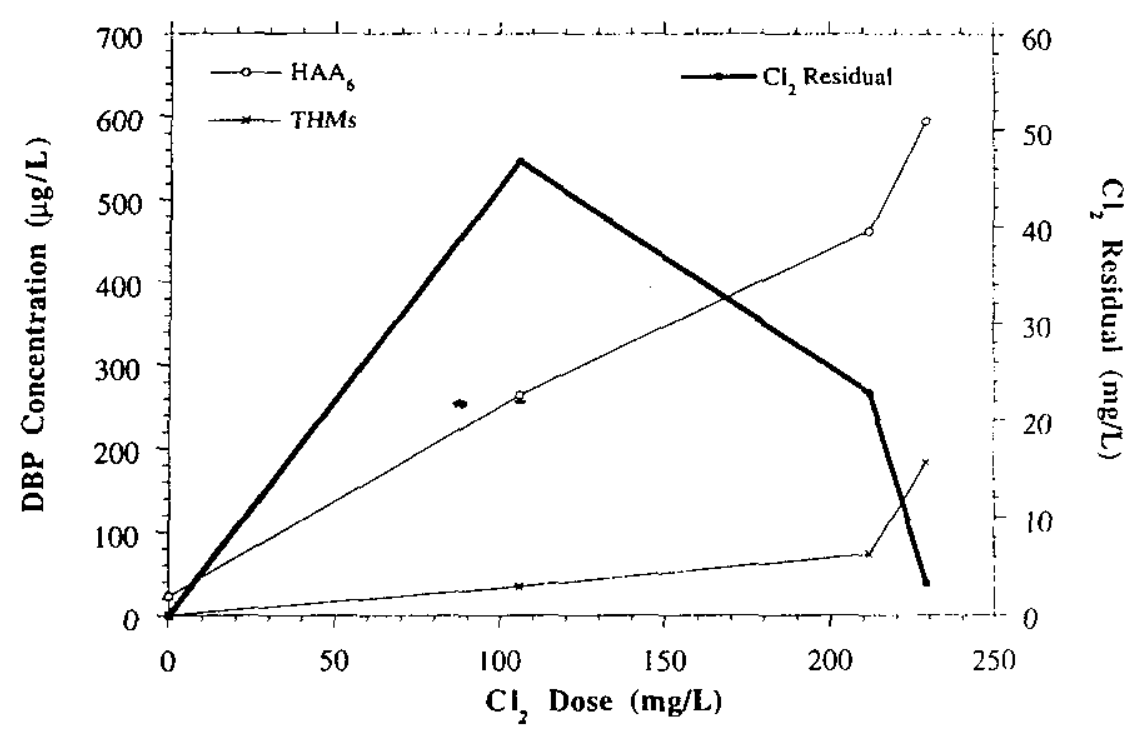

Figure 9 Breakpoint chlorination curve for raw effluent (TOC $=16.1 \mathrm{mg} / \mathrm{L} ; \mathrm{NH}_{3}-\mathrm{N}$ $=27.9 \mathrm{mg} / \mathrm{L}$ ). $D B P=$ disinfection by-products.

Titrage avec du chlore de l'effluent secondaire brut et formation de sousproduits de la désinfection (COT $=16.1 \mathrm{mg} / \mathrm{L} ; \mathrm{NH}_{3}-\mathrm{N}=27.9 \mathrm{mg} / \mathrm{L}$ ).

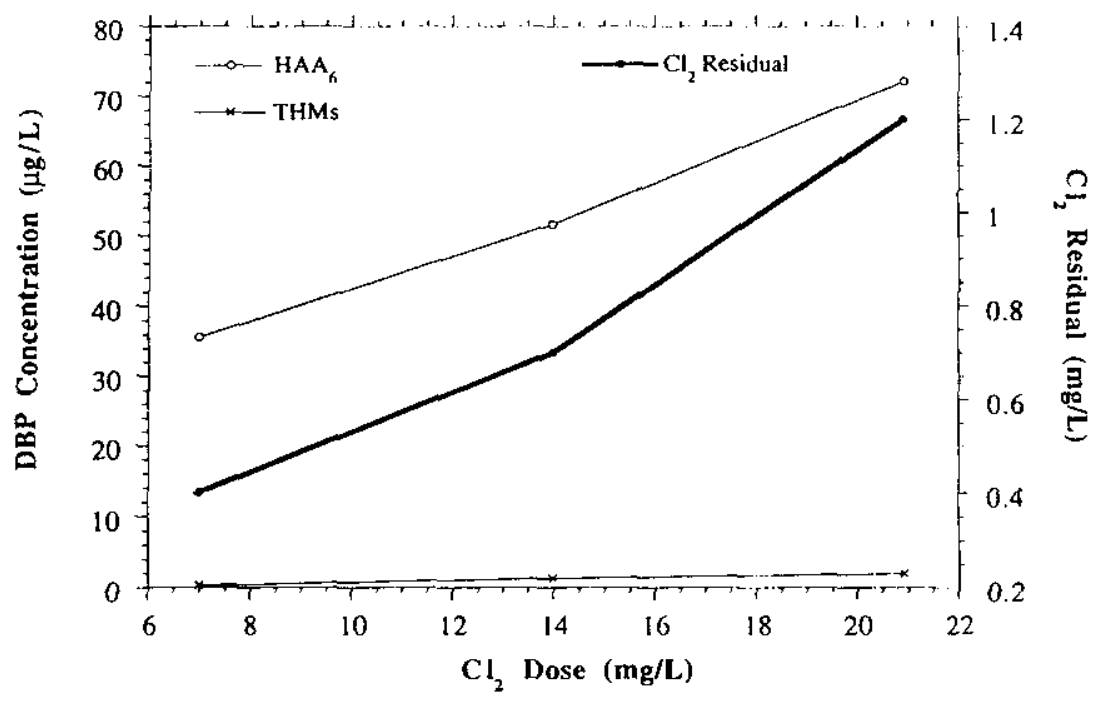

Figure 10 Breakpoint chlorination curve for biotreated effluent ( $D O C=6.9 \mathrm{mg} / \mathrm{L} ; \mathrm{NH}_{3}$ $N=1.84 \mathrm{mg} / \mathrm{L}$ ). $D B P=$ disinfection by-products.

Titrage avec du chlore de l'effluent secondaire traité et formation de sousproduits de la désinfection ( $\mathrm{COD}=6.9 \mathrm{mg} / \mathrm{L} ; \mathrm{NH}_{3}-\mathrm{N}=1.84 \mathrm{mg} / \mathrm{L}$ ). 
Nitrification was also studied within BDOC reactors, with an almost complete conversion of $\mathrm{NH}_{3}-\mathrm{N}$ to $\mathrm{NO}_{3}{ }^{-}-\mathrm{N}$. Final nitrate nitrogen levels exceed the primary standard of $10 \mathrm{mg} / \mathrm{L}$ (Fig. 11), suggesting that nitrate may be a limiting factor in a potable reuse SAT system.

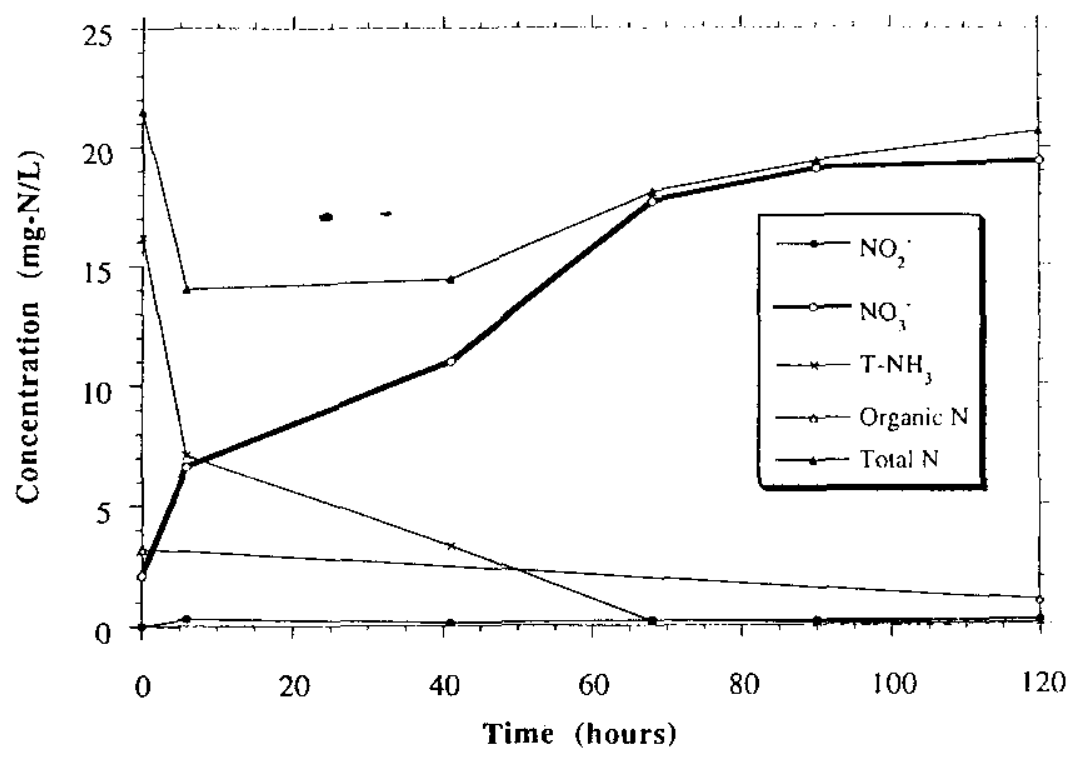

Figure 11 Kinetics of denitrification in $B D O C$ reactors.

Cinétique de la dénitrification se produisant dans les réacteurs CODB.

\section{CONCLUSIONS}

This bench scale simulation of SAT technology for the potable reuse of wastewater effluents has indicated that:

1) The secondary wastewater effluent organic matter studied has a larger biodegradable fraction $(40-50 \%$ ) than a typical surface water (approximately $10 \%$ ).

2) Ozone is more effective at increasing the biodegradability of a typical surface water NOM than the wastewater effluent organic matter studied.

3) Biotreatment, and more specifically, ozonation followed by biotreatment, significantly reduces the DBP formation potential of waste water effluent.

\section{TOWARDS A POTABLE WATER SAT SYSTEM}

The use of ozone for effluent pretreatment can also serve other functions, including microbial inactivation and the creation of readily degradable organic 
matter that can be utilized for denitrification within anaerobic (perched water) regions of the vadose zone. We envision an integrated potable water system comprised of pre- $\mathrm{O}_{3}$, SAT, and post-disinfection upon recovery. Since nitrate may be a limiting factor, it may be more advantageous to utilize a denitrified effluent. Previous related pilot and field work has shown effective virus removal by SAT (GERBA et al., 1991).

\section{ACKNOWLEDGEMENTS}

The work reported herein was supported by the AWWA Research Foundation (Michelle Cline, Project Manager), with additional support provided by the City of Phoenix (Michael Gritzuk), Tucson Water (Bruce Johnson), and the Salt River Project (Jan Miller).

\section{BIBLIOGRAPHIC REFERENCES}

AMY G.L., WILSON L.G., CONROY A., CHAHBANDOUR J., ZHAI W., SIDDIQUI M., 1993. Fate of chlorination byproducts and nitrogen species during effluent recharge and Soil Aquifer Treatment (SAT). Water Environ. Res., 65: 726-734.

AMY G.L., 1992. Biodegradability of natural organic matter: A comparison of methods (BDOC and $A O C$ ) and correlations with chemical surrogates. In AWWA 1992 Annual Conference Proceedings, Vancouver, B.C., Canada, June, 523-542.

ASANO T. (Editor), 1985. Artificial Recharge of Groundwater, Butterworth Publishers, Boston.

BOUWER H., RICE, R.C., 1984. Renovation of wastewater at the 23rd Avenue Rapid Infiltration Project. Journal WPCF, 56: 1: 76-83.

BOUWER H., RICE R.C., LANCE J.C., GILBERT R.C., 1980. Rapid-infiltration research at Flushing Meadows project, Arizona. Journal WPCF, 52: 10: 2457-2470.

BOUWER H.. LANCE J.C., RIGGS M.S., 1974. High-rate land treatment II: Water quality and economic aspects of the Flushing Meadows project. Journal WPCF, 46: 5: 844-859.
GERBA C.P., POWELSON D.K., YAHYA M.T., WILSON L.G., AMY G.L., 1991. Fate of viruses in treated sewage effluent during soil aquifer treatment designed for wastewater reclamation and reuse. Wat. Sci. Tech., 24: 9: 95-102

JOHNSON A.I., FINLAYSON D.J. (Editors), 1989. Artificial Recharge of Ground Water, American Society of Civil Engineers.

KNOPPERT P.L., OSKAM G., VREEDENBURGH E.G.H, 1980. An overview of European water treatment practice. Journal of AWWA, 72: 11: 592-599.

LEENHEER J.A., 1981. Comprehensive approach to preparative isolation and fractionation of dissolved organic carbon from natural waters and wastewaters. Environ. Sci. Technol., 15: 5: 578-587.

MILTNER R.J., SKUKAIRY H.M., SUMMERS R.S., 1992. Disinfection by-product formation and control by ozonation and biotreatment. Journal of AWWA, 84: 11:53-62.

MOGREN E.M., SCARPINO P., SUMMERS R.S., 1990. Measurement of Biodegradable Dissolved Organic Carbon in Drinking Water. In AWWA 1990 Annual Conference Proceedings, Cincinnati, $\mathrm{OH}$, USA, June 18-21, 573-587. 
MURPHY B.M., 1993. Ozone Induced Conversion of DBP Precursors (DOC) to Biodegradable By-Products ( $B D O C)$, Masters Thesis, University of Colorado, Boulder.

ROBSON C.M., RICE R.G., 1991. Wastewater ozonation in the USA - history and current status- 1989. Ozone Science \& Engineering, 13: $23-40$.

SAUNDERS F.M., DICK R.I., 1981. Effect of mean-cell residence time on organic composition of activated sludge effluents. Journal WPCF, 53: 2: 201-215.

SERVAIS P., BILLEN G., VENTRESQUE C., BABLON G.P., 1991. Microbial activity in
GAC Filters at the Choisy-le-Roi treatment plant. Journal of AWWA, 83: 2: 62-68.

VOLK C., RENNER C., ROCHE P., PAILLARD H., JORET J.C., 1993. Effects of ozone on the production of biodegradable dissolved organic carbon (BDOC) during water treatment. Ozone Science \& Engineering. 15: 389-404.

THURMAN E.M., 1985. Organic Geochemistry of Natural Waters, ISBN 90-247-31437, Martinus Nijhotf/Dr. W. Junk Publishers, Boston. 